\title{
Trajectory Control of Aerial Vehicles for Live-line Maintenance Work (1st Report, Control of Derricking Action by the Linearization of Servo Valve)
}

\author{
Lin LAN, Katsunobu KONISHI ${ }^{* 3}$ and Masaharu KIMURA \\ ${ }^{* 3}$ Department of Mechanical Engineering, The University of Tokushima, \\ 2-1 Minami-josanjima, Tokushima-shi, Tokushima, 770-8506 Japan
}

\begin{abstract}
In this paper, as the first step of trajectory control of aerial vehicles for live-line maintenance work, by servo valve attached to the derricking cylinder, a trajectory control method of bucket in the vertical plane is discussed. Here, we reorganized the equation of motion for the aerial vehicle and linearized the servo value by introducing the current compensation. Based on these equations, we derived the simple model of the controlled variable corresponding to the altitude of the bucket gravity center and the control rule. Simulations demonstrate that current compensation can improve the precision of trajectory control effectively, and good results can be obtained for the changing of the bucket altitude and sinusoidal reference trajectory by using the proposed method.
\end{abstract}

Key Words : Servo Valve, Current Compensation, Nonsymmetrical Cylinder, Trajectory Control, Disturbance Observer, Aerial Vehicle

\section{1. 緒言}

最近の配電線活線工事では, 高所作業車のバケット 上に双腕のマニピュレータを搭載し, 作業者がマスタ スレーブ方式で操縦するロボット工法が使用されてい る(1) (3). これは, 作業者を重労働や危険作業から解放 するという意味で将来性が高く評価されているが, バ ケット質量がブームの剛性に比べて相対的に大きくな るために, 起伏角や旋回角を操作したときにバケット が摇れ, 作業能率の改善の妨げになっている.このよ うな観点から, 著者の一部は高所作業車のモデリング と振動制御を検討し, 起伏シリンダなどに取付けた小 形プランジャによって, 簡単に振動抑制できることを 示した ${ }^{(4)(5)}$. 本論文では次の段階としてバケットの三 次元軌道制御を想定し, その第一歩として, バケット 重心の高さを起伏シリンダに取付けたサーボ弁で制御 する方法を検討する.

軌道制御の立場から高所作業車の特性を考えると， 次のように要約できる.すなわち, (1)バケット重量

\footnotetext{
* 原稿受付 2003 年 8 月 11 日

*1 徳島大学大学院博士後期課程 (亚 770-8506 徳島市南常三島 町 2-1).

*2 正員, 徳島大学工学部 ( 770-8506 徳島市南常三島町 2-1).

E-mail : konishi@me.tokushima-u.ac.jp
}

を支えるためにシリンダには大きな負荷圧力が作用し ている. したがって, サーボ弁入力電流の正負に対し てピストン速度の絶対值が異なり, 電流からピストン 速度までの特性が非線形になっている，（2）多数の振 動モードが存在し, その固有振動数が接近しているた めに, 高ゲインのフィードバックを施すと発振の可能 性がある, ( 3 ) 軌道追従の速度は一次振動モードの固 有振動数以下で良い, などである。この（2）と（３）を 考虑して本論文では, 一次振動モードによってバケッ ト重心高さの制御モデルを作成し，フィードバックゲ インは低く押さえるものとする.

一方，（1）の非線形性は軌道追従精度を低下させる ので, なんらかの方法で線形化する必要がある。これ に関する文献として, 阿波ら ${ }^{(6)}$ は, 片ロッドシリンダ で剛体質量を駆動する問題を扱い, 一次遅れ要素を介 してピストン速度を高ゲインで電流側にフィードバッ クする方法を提案し, これをべースにして高速の軌道 制御系を構成している. また, 横田ら (7) は, 油圧ショ ベルのバケットの軌道制御問題を扱い, 電流から関節 回転角までの線形モデルに対して高ゲインの外乱オブ ザーバを適用し，等価入力外乱を正確に推定すること が精度向上のために有効であると結論している。これ らの方法は線形化を達成する手段ではあるが, マイナ 
ループに高ゲインのフィードバックを含んでいるの で, 高所作業車に適用した場合には高次モードを発振 させる可能性がある。そこで, 本論文では, 上記 (3) のように軌道追従の周波数が低いこと，および非線形 性が負荷圧力に依存していることを考慮して, 電流波 形を準開ループ的に調整するものとする，具体的に は，電流指令值と実際の電流の間に電流補正ゲインを 導入し, 電流の正負および負荷圧力の大小に応じて, このゲインを調整する。

以下では, 高所作業車のモデルの概要, その運動方 程式, 制御モデル, 制御則およびシミュレーション結 果について述べる. 制御モデルでは電流補正ゲインの 導出法を詳しく述べ, シミュレーションでは軌道追従 精度の向上のためにそれが有効であることを示す。

\section{2. 高所作業車のモデル}

本論文で取扱ったのは，トラックに架装された四段 伸縮形ブームの高所作業車(4)であり，その運動モデル は図 1 のようになっている.モデル作成に用いた仮

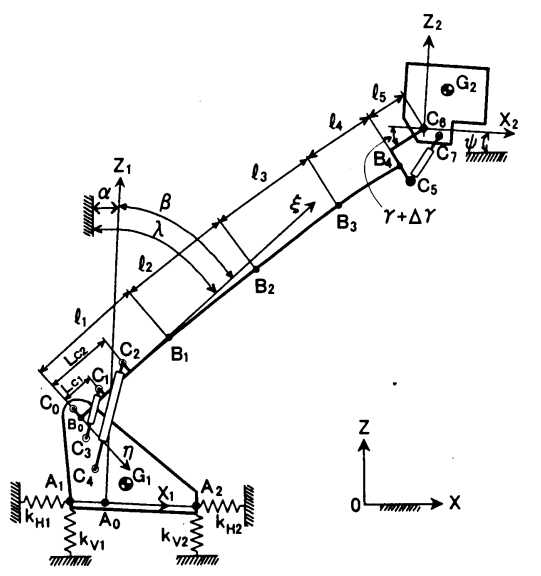

Fig. 1 Schematic diagram of the aerial vehicle ${ }^{(4)}$

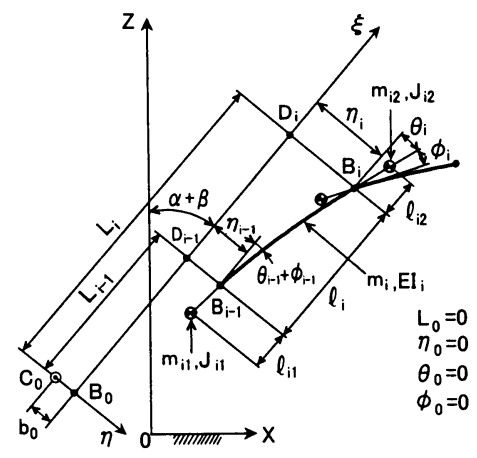

Fig. 2 Deflection of the boom ${ }^{(4)}$
定, モデルの各部分に設定した変数, およびシミュレ ーションに用いたパラメータを以下に要約する。

台車・旋回台は一体化した剛体, 台車を支えるアウ トリガは上下左右方向に作用するばねとしている. 台 車・旋回台の変位は, 台車部分に固定された点 $\mathrm{A}_{0}$ の 水平変位 $x$, 鉛直変位 $z$ および旋回軸 $Z_{1}$ の傾斜角 $\alpha$ で表す.ブームの各段は図 2 のように $\mathrm{B}_{i-1}$ と $\mathrm{B}_{i}$ との 中間部分は一様なはり要素で近似し, 外側の部分では 剛体として扱う。ここで, $\mathrm{B}_{i}$ はブーム $i$ と $i+1$ が重 なっている部分の中点であり, $\mathrm{B}_{i}$ ではブーム間に回 転変位が生じると仮定する.ブームに関する変数は, ブーム基部に固定した $\xi$ 軸と旋回軸のなす角 $\beta$, 点 $\mathrm{B}_{1} \sim \mathrm{B}_{4}$ における $\xi$ 軸からの変位 $\eta_{1} \sim \eta_{4}, \xi$ 軸に対す る傾き $\theta_{1} \sim \theta_{4}$, および点 $\mathrm{B}_{1} \sim \mathrm{B}_{3}$ における隣接ブーム 間の回転変位 $\phi_{1} \sim \phi_{3}$ である.レベリングシリンダに 関しては, 下部と上部のシリンダはホースで連結され ているので, 同期して動くが, ホースおよびシリンダ 内の作動油の圧縮性を考慮してバケットの微小な回転 角 $\Delta r$ を導入している，この圧縮がない場合には, 第 4 ブーム右端とバケット床面のなす角は $r=90^{\circ}-\beta$ と なっている. バケットとこれに搭載されたマニピュレ 一夕は剛体として扱う。 バケット床面と水平軸 $X$ の なす角は $\phi=\alpha+\theta_{4}+\Delta \gamma$ である.

起伏シリンダとサーボ弁のモデルは図 3 であり, サ 一ボ弁はゼロラップ形と仮定している。ここで $Q$ は 流量, $P$ は圧力, $V$ は作動油の体積, $A_{D C}$ はピストン 受圧面積, $u$ はサーボ弁の開度, $r$ は起伏シリンダの 長さである. 以上より, 高所作業車の運動を次の 16 次元ベクトル

$$
\begin{aligned}
\boldsymbol{q} & =\left[x, z, \alpha, \beta, \eta_{1}, \theta_{1}, \phi_{1},\right. \\
& \left.\eta_{2}, \theta_{2}, \phi_{2}, \eta_{3}, \theta_{3}, \phi_{3}, \eta_{4}, \theta_{4}, \Delta \gamma\right]^{T}
\end{aligned}
$$

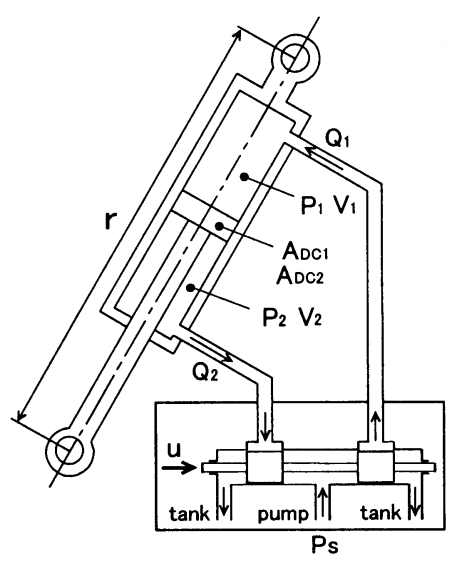

Fig. 3 Derricking cylinder and servo value 
と図 3 に示した $P_{1}, P_{2}, Q_{1}, Q_{2}$ を用いて記述する.

モデル各部の寸法や質量等は表 1 に示している。こ れらを種類別に説明すると次のようになる， $m_{G 1}$ と $m_{G 2}$ は台車・旋回台とバケットの質量, $m_{1} \sim m_{42}$ は図 2 に示したブーム各部分の質量, $J_{G 1}, J_{G 2}, J_{11} \sim J_{42}$ は 台車・旋回台, バケット，ブーム各部分の慣性モーメ ント, $E I_{1} \sim E I_{4}$ はブーム各段の曲げ剛性, $K_{H 1} \sim K_{V 2}$ と $K_{B 1} \sim K_{B 3}$ はアウトリガおよび $\mathrm{B}_{1} \sim \mathrm{B}_{3}$ 点における 隣接ブーム間の回転のばね定数, $l_{G 1} \sim l_{C 4}$ と $h_{G 1} \sim h_{C 4}$ はそれぞれ $Z_{1}$ 軸と $X_{1}$ 軸から添字が表す点への距離, $l_{G 2} \sim l_{C 7}$ と $h_{G 2} \sim h_{C 7}$ はそれぞれ $Z_{2}$ 軸と $X_{2}$ 軸から $\mathrm{G}_{2}$, $\mathrm{C}_{7}$ への距離, $b_{0} \sim b_{6}$ はブーム中心線から点 $\mathrm{C}_{0}, \mathrm{C}_{1}$, $\mathrm{C}_{2}, \mathrm{C}_{5}, \mathrm{C}_{6}$ までの距離, $l_{1} \sim L_{4}$ は図 1 と図 2 に示した 距離, $A_{L C}$ はレベリングシリンダヘッド側の受圧面 積， $V_{L C}$ は上下レベリングシリンダ合計のへッド側作 動油の体積, $K_{\text {oll }}$ は作動油の体積弾性係数である。な お，本論文では制御を円滑に行うために，文献（４）に 対して, 起伏シリンダの受圧面積をへッド側で $A_{D C 1}=200 \mathrm{~cm}^{2}$, ピストン側で $A_{D C 2}=100 \mathrm{~cm}^{2}$ に変更 した.

\section{3. 運動方程式}

$3 \cdot 1$ 高所作業車の運動方程式 文献 (4)ではプ ランジャの変位を入力とする運動方程式が示されてい

Table 1 Parameters of the aerial vehicle ${ }^{(4)}$

\begin{tabular}{|c|c|c|c|c|c|}
\hline \multicolumn{6}{|c|}{ Carrier } \\
\hline$m_{G I}[\mathrm{~kg}]$ & 5505 & $l_{G_{1}}[\mathrm{~m}]$ & 0.370 & $h_{G 1}[\mathrm{~m}]$ & 0.069 \\
\hline$J_{G_{1}}\left[\mathrm{kgm}^{3}\right]$ & 3500 & $l_{A 1}[\mathrm{~m}]$ & 0.190 & $h_{A 1}[\mathrm{~m}]$ & 0.000 \\
\hline$K_{H 1}[\mathrm{~N} / \mathrm{m}]$ & $1.8 \mathrm{E}+5$ & $l_{A 2}[\mathrm{~m}]$ & 2.663 & $h_{A 2}[\mathrm{~m}]$ & 0.000 \\
\hline$K_{H 2}[\mathrm{~N} / \mathrm{m}]$ & $1.8 \mathrm{E}+5$ & $l_{\mathrm{CO}}[\mathrm{m}]$ & 0.650 & $h_{\mathrm{CO}}[\mathrm{m}]$ & 2.015 \\
\hline$K_{n}[\mathrm{~N} / \mathrm{m}]$ & $2.4 \mathrm{E}+6$ & $l_{C 3}[\mathrm{~m}]$ & 0.501 & $h_{C_{3}}[\mathrm{~m}]$ & 1.848 \\
\hline $\mathrm{N} / \mathrm{m}]$ & $2.4 \mathrm{E}+6$ & $l_{C_{4}}[\mathrm{~m}]$ & 0.125 & $h_{\mathrm{C}}[\mathrm{m}]$ & 1.450 \\
\hline \multicolumn{6}{|c|}{ Bucket } \\
\hline$m_{G 2}[\mathrm{~kg}]$ & 1105 & $l_{G 2}[\mathrm{~m}]$ & 0.450 & $h_{\mathrm{G} 2}[\mathrm{~m}]$ & 0.800 \\
\hline$J_{G_{2}}\left[\mathrm{kgm}^{2}\right]$ & 250.0 & $l_{C 7}[\mathrm{~m}]$ & 0.114 & $h_{C 7}[\mathrm{~m}]$ & 0.193 \\
\hline \multicolumn{6}{|c|}{ Boom } \\
\hline$m_{1}[\mathrm{~kg}]$ & 300.1 & $J_{32}\left[\mathrm{kgm}^{2}\right]$ & 0.711 & $L_{C_{2}}[\mathrm{~m}]$ & 2.150 \\
\hline$m_{11}[\mathrm{~kg}]$ & 51.16 & $J_{41}\left[\mathrm{kgm}^{2}\right]$ & 0.107 & $L_{1}[\mathrm{~m}]$ & 2.405 \\
\hline$m_{12}[\mathrm{~kg}]$ & 69.73 & $J_{42}\left[\mathrm{kgm}^{2}\right]$ & 6.310 & $L_{2}[\mathrm{~m}]$ & 5.088 \\
\hline$m_{2}[\mathrm{~kg}]$ & 177.0 & $l_{1}[\mathrm{~m}]$ & 2.405 & $L_{3}[\mathrm{~m}]$ & 7.816 \\
\hline$m_{21}[\mathrm{~kg}]$ & 27.38 & $l_{11}[\mathrm{~m}]$ & 0.205 & $L_{4}[\mathrm{~m}]$ & 10.19 \\
\hline$m_{22}[\mathrm{~kg}]$ & 40.65 & $l_{12}[\mathrm{~m}]$ & 0.208 & $b_{0}[\mathrm{~m}]$ & 0.247 \\
\hline$m_{3}[\mathrm{~kg}]$ & 123.0 & $l_{2}[\mathrm{~m}]$ & 2.683 & $b_{1}[\mathrm{~m}]$ & 0.268 \\
\hline$m_{31}[\mathrm{~kg}]$ & 13.19 & $l_{21}[\mathrm{~m}]$ & 0.208 & $b_{2}[\mathrm{~m}]$ & 0.312 \\
\hline$m_{32}[\mathrm{~kg}]$ & 38.80 & $l_{22}[\mathrm{~m}]$ & 0.146 & $b_{s}[\mathrm{~m}]$ & 0.034 \\
\hline$m_{4}[\mathrm{~kg}]$ & 85.87 & $l_{3}[\mathrm{~m}]$ & 2.728 & $b_{6}[\mathrm{~m}]$ & 0.181 \\
\hline$m_{41}[\mathrm{~kg}]$ & 8.120 & $l_{31}[\mathrm{~m}]$ & 0.146 & $E I_{1}\left[\mathrm{Nm}^{2}\right]$ & $2.9 \mathrm{E}+7$ \\
\hline$m_{42}[\mathrm{~kg}]$ & 108.8 & $l_{32}[\mathrm{~m}]$ & 0.112 & $E I_{2}\left[\mathrm{Nm}^{2}\right]$ & $2.1 \mathrm{E}+7$ \\
\hline$J_{11}\left[\mathrm{kgm}^{2}\right]$ & 2.042 & $l_{4}[\mathrm{~m}]$ & 2.374 & $E I_{3}\left[\mathrm{Nm}^{2}\right]$ & $1.0 \mathrm{E}+7$ \\
\hline$J_{12}\left[\mathrm{kgm}^{2}\right]$ & 2.807 & $l_{41}[\mathrm{~m}]$ & 0.112 & $E I_{4}\left[\mathrm{Nm}^{2}\right]$ & $8.6 \mathrm{E}+6$ \\
\hline$J_{21}\left[\mathrm{kgm}^{2}\right]$ & 0.958 & $l_{42}[\mathrm{~m}]$ & 0.385 & $K_{B 1}[\mathrm{Nm} / \mathrm{rad}]$ & $4.5 \mathrm{E}+6$ \\
\hline$J_{22}\left[\mathrm{kgm}^{2}\right]$ & 1.128 & $l_{s}[\mathrm{~m}]$ & 0.771 & $K_{B 2}[\mathrm{Nm} / \mathrm{rad}]$ & $3.0 \mathrm{E}+6$ \\
\hline$J_{31}\left[\mathrm{kgm}^{2}\right]$ & 0.280 & $L_{C_{1}}[\mathrm{~m}]$ & 0.800 & $K_{B 3}[\mathrm{Nm} / \mathrm{rad}]$ & $2.5 \mathrm{E}+6$ \\
\hline \multicolumn{6}{|c|}{ Cylinder } \\
\hline & & $A_{L C}\left[\mathrm{~m}^{2}\right]$ & $\begin{array}{l}5.7 \mathrm{E}-3 \\
2.8 \mathrm{E}-3\end{array}$ & $K_{\text {oil }}[\mathrm{Pa}]$ & $1.4 \mathrm{E}+9$ \\
\hline
\end{tabular}

るが，ここでは，起伏シリンダの発生力 $F_{D C}$ を入力と する運動方程式を導く，導出法は基本的に同じである ので, 概要のみを示す.

まず, 台車・旋回台, ブーム, バケットおよびレべ リングシリンダについてカ学的エネルギーを計算し, これを合計したものを

$$
\begin{aligned}
T & =\frac{1}{2} \dot{\boldsymbol{q}}^{T} \boldsymbol{M}(\boldsymbol{q}) \dot{\boldsymbol{q}} \\
U & =\frac{1}{2} \boldsymbol{q}^{T} \boldsymbol{K}(\boldsymbol{q}) \boldsymbol{q} \\
V & =\boldsymbol{V}(\boldsymbol{q}) \ldots \ldots \ldots
\end{aligned}
$$

と表す。ここで, $T$ は運動エネルギー, $U$ は弾性エネ ルギー, $V$ は重力による位置エネルギーである。次 に, 起伏シリンダ発生力 $F_{D C}$, バケット重心に作用す る水平方向と鉛直方向の外力 $F_{x}, F_{z}$ および重心ま わりのモーメント $M_{x z}$ が高所作業車に与える動力を 計算し,

$$
W_{\mathrm{ext}}=\ddot{\boldsymbol{q}}^{T}\left[\boldsymbol{B}(\boldsymbol{q}) F_{D C}+\boldsymbol{D}(\boldsymbol{q}) \boldsymbol{F}_{\text {out }}\right]
$$

と表す。ここで, $\boldsymbol{F}_{\text {out }}=\left[F_{x}, F_{z}, M_{x z}\right]^{T}$ である。最後 に, 式(2)〜（5)にラグランジュ法を適用して運動方 程式を求めると, 次式が得られる.

$$
\begin{array}{r}
\boldsymbol{M}(\boldsymbol{q}) \ddot{\boldsymbol{q}}+\boldsymbol{H}(\boldsymbol{q}, \dot{\boldsymbol{q}})+\boldsymbol{C}(\boldsymbol{q}) \dot{\boldsymbol{q}}+\boldsymbol{K}(\boldsymbol{q}) \boldsymbol{q} \\
\quad=\boldsymbol{B}(\boldsymbol{q}) F_{D C}+\boldsymbol{G}(\boldsymbol{q})+\boldsymbol{D}(\boldsymbol{q}) \boldsymbol{F}_{\text {out }} \cdots
\end{array}
$$
ここで,

$$
\begin{aligned}
& \boldsymbol{H}(\boldsymbol{q}, \dot{\boldsymbol{q}})=\dot{M}(\boldsymbol{q}) \dot{\boldsymbol{q}}-\frac{1}{2} \partial\left[\dot{\boldsymbol{q}}^{T} \boldsymbol{M}(\boldsymbol{q}) \dot{\boldsymbol{q}}\right] / \partial \boldsymbol{q} \quad \cdots(7) \\
& \boldsymbol{C}(\boldsymbol{q})=v_{1} \boldsymbol{M}(\boldsymbol{q})+v_{2} \overline{\boldsymbol{K}}(\boldsymbol{q}) \\
& =v_{1} \boldsymbol{M}(\boldsymbol{q})+v_{2}\left(\boldsymbol{K}(\boldsymbol{q})+k_{D C} \boldsymbol{B}(\boldsymbol{q}) \boldsymbol{B}^{T}(\boldsymbol{q})\right) \\
& \boldsymbol{G}(\boldsymbol{q})=-\partial \boldsymbol{V}(\boldsymbol{q}) / \partial \boldsymbol{q}
\end{aligned}
$$

である. $\boldsymbol{C}(\boldsymbol{q})$ はシステムに減衰を与えるための行列 であり，式（３）で定義された剛性行列 $\boldsymbol{K}$, 起伏シリン ダ内作動油の圧縮性に対応する剛性行列 $k_{D C} \boldsymbol{B}(\boldsymbol{q}) \boldsymbol{B}^{T}(\boldsymbol{q})$ および質量行列 $\boldsymbol{M}$ から比例減衰とし て構成している。ここで， $k_{D C}$ はロッドから見た起伏 シリンダのばね定数である. 定数 $v_{1}$ と $v_{2}$ は, $\boldsymbol{M}$ と $\overline{\boldsymbol{K}}$ から構成される振動系の $\beta=45^{\circ}$ での一次モードと 二次モードの隇衰比が 0.05 となるょうに決定してい る.

本論文の以下の部分では, 高所作業車が静止してい るときの $\boldsymbol{q}, F_{D C}, \beta, r な と ゙ の$ 值を, $\boldsymbol{q}^{*}, F_{D C}{ }^{*}, \beta^{*}$, $r^{*}$ のように表すものとする， $\boldsymbol{q}^{*}$ と $F_{D C}{ }^{*}$ の方程式は 式 (6) から次のようになる ( $\boldsymbol{F}_{\text {out }}=0$ とする).

$$
\boldsymbol{K}\left(\boldsymbol{q}^{*}\right) \boldsymbol{q}^{*}=\boldsymbol{B}\left(\boldsymbol{q}^{*}\right) F_{D C}{ }^{*}+\boldsymbol{G}\left(\boldsymbol{q}^{*}\right)
$$

この式から, $\beta^{*}$ を气えると, $\boldsymbol{q}^{*}$ と $F_{D C}{ }^{*}$ を求めるこ とができる. 
$3 \cdot 2$ サーボ弁と起伏シリンダの運動方程式 起 伏シリンダに関する方程式は, 図 3 より

$$
\begin{aligned}
& Q_{1}=A_{D C 1} \frac{d r}{d t}+\frac{V_{1}}{K_{\mathrm{oil}}} \frac{d P_{1}}{d t} \\
& Q_{2}=A_{D C 2} \frac{d r}{d t}-\frac{V_{2}}{K_{\mathrm{oll}}} \frac{d P_{2}}{d t} \\
& F_{D C}=A_{D C 1} P_{1}-A_{D C 2} P_{2}
\end{aligned}
$$

となる.ここで, 作動油の体積 $V_{1}$ と $V_{2}$ は $l_{D C 1}$ と $l_{D C 2}$ を定数として, 次式で与えられるものとする.

$$
\begin{aligned}
& V_{1}=A_{D C 1}\left(r-l_{D C 1}\right) \\
& V_{2}=A_{D C 2}\left(l_{D C 2}-r\right)
\end{aligned}
$$

一方, サーボ弁はゼロラップ形と仮定しているので, その流量は, 弁開度が非負 $(u \geq 0)$ の場合には

$$
\begin{aligned}
& Q_{1}=K_{Q} u \operatorname{sgn}\left(P_{S}-P_{1}\right) \sqrt{\left|P_{S}-P_{1}\right|} \\
& Q_{2}=K_{Q} u \operatorname{sgn}\left(P_{2}\right) \sqrt{\left|P_{2}\right|} \cdots \cdots \cdots \cdots \cdots \cdots \cdots \cdots
\end{aligned}
$$

となり, 逆に $u<0$ の場合には

$$
\begin{aligned}
& Q_{1}=K_{Q} u \operatorname{sgn}\left(P_{1}\right) \sqrt{\left|P_{1}\right|} \cdots \cdots \cdots \cdots \cdots \\
& Q_{2}=K_{Q} u \operatorname{sgn}\left(P_{S}-P_{2}\right) \sqrt{\left|P_{S}-P_{2}\right|}
\end{aligned}
$$

となる.ここで, $K_{Q}$ は流量係数である. 弁開度 $u$ は, サーボ弁入力電流 $i$ に対する一次遅れ系の出力とし て, 次式で与えられるものとする.

$$
u=\frac{K_{u}}{1+T_{u} s} i
$$

$3 \cdot 2$ 節で導入した定数の值として, シミュレーショ ンでは,

$$
\begin{aligned}
& l_{D C 1}=1.46 \mathrm{~m}, l_{D C 2}=2.7 \mathrm{~m} \\
& K_{Q}=6.45 \mathrm{~m}^{2} / \mathrm{s}(\mathrm{Pa})^{1 / 2} \\
& K_{u}=0.0217 \mathrm{~mm} / \mathrm{mA}, T_{u}=2 \mathrm{~ms}
\end{aligned}
$$

を用いる，また，サーボ弁の供給圧力は $P_{S}=21 \mathrm{MPa}$ とする。

$3 \cdot 3$ 運動方程式の数値計算法 方程式 (6) と方 程式(11)〜 (19) は, シリンダ発生力 $F_{D C}$ とピストン速 度 $\dot{r}$ をして連成しているが，この連成問題を解くた

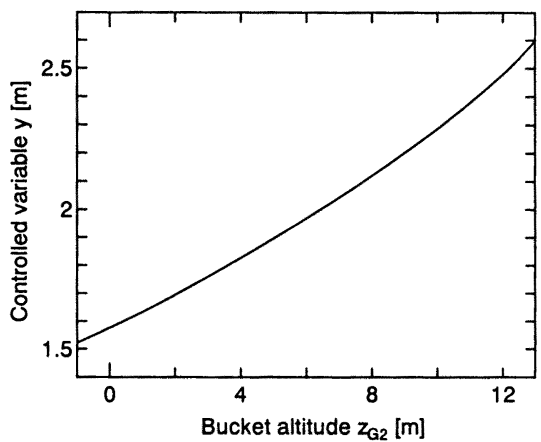

Fig. 4 Relation between bucket altitude and controlled variable
めに, $F_{D C}$ の值を仮定して全体が整合するまで刻み時 間幅 $\Delta t$ ごとに反復計算を行った，具体的には，時刻 $t$ の変数值が求まったとき, 次の時刻 $t+\Delta t$ における $F_{D C}$ の值の仮定し, 式 (6)から $\boldsymbol{q}(t+\Delta t)$ をニューマ 一クのベー夕法で計算する. $\boldsymbol{q}(t)$ と $\boldsymbol{q}(t+\Delta t)$ から刻 みの中央時刻における $\dot{r}$ が計算されるので, 式(11) 〜 (19) を中心差分法で離散化すれば， $t+\Delta t$ における $P_{1}$ と $P_{2}$ が求められる.この圧力から $F_{D C}$ を計算し, 先に仮定した値との差がなくなるまで反復計算を行っ た. 刻み時間は $\Delta t=0.5 \mathrm{~ms}$ としたが, 反復回数は約 3 回であった。

\section{4. 制御モデル}

$4 \cdot 1$ 制御量 本論文の制御問題では, 入力信号 はサーボ弁の電流 $i$, 出力信号はバケットの重心の高 さ $z_{G 2}$ であるが, この過程には強い非線形が含まれて いる。そこで，中間の信号として起伏シリンダの長 $r$ を考えると, $i$ から $r$ の過程は緒言に述べた電流補正 ゲインの導入によって，ある程度まで線形化が可能で ある。一方, $r$ から $z_{G 2}$ の過程の非線形性は, 弾性変 形を除けば幾何学的なものであるから, 変数変換によ ってその影響を緩和できる。そこで本論文では，高所 作業車に弾性変形がない場合 (変数 $\boldsymbol{q}$ の中で $\beta$ 以外の ものがすべて零)を想定して, $z_{G 2}$ からシリンダの長さ $r$ を逆算し，これを $y$ と表す。そして，yを制御量と して用いる。

$$
\begin{aligned}
& z_{G 2} \text { と } y \text { の関係は, 図 } 1 \text { によって次式で与えられる. } \\
& y=\left(n_{1}+n_{2} \sin \bar{\beta}+n_{3} \cos \bar{\beta}\right)^{1 / 2} \\
& \bar{\beta}=\cos ^{-1}\left[\left(z_{G 2}-h_{c 0}-h_{G 2}\right) /\left(n_{4}^{2}+\left(b_{0}-b_{6}\right)^{2}\right)^{1 / 2}\right] \\
& -\tan ^{-1}\left[\left(b_{0}-b_{6}\right) / n_{4}\right] \\
& n_{1}=\left(b_{2}-b_{0}\right)+\left(h_{C 0}-h_{C 4}\right)+\left(l_{c 4}-l_{c 0}\right)^{2}+l_{c 2}{ }^{2} \\
& n_{2}=2\left[\left(l_{c 4}-l_{c 0}\right) l_{c 2}+\left(h_{c 0}-h_{c 4}\right)\left(b_{2}-b_{0}\right)\right] \\
& n_{3}=2\left[\left(h_{c 0}-h_{c 4}\right) l_{c 2}-\left(l_{c 4}-l_{c 0}\right)\left(b_{2}-b_{0}\right)\right] \\
& n_{4}=l_{1}+l_{2}+l_{3}+l_{4}+l_{5}
\end{aligned}
$$

ここで, $\bar{\beta}$ は弾性変形がない場合の起伏角, 添字付の $b, h, l$ は表 1 に関して説明したように，その添字が 示している点に関する長さである。 $z_{G 2}$ と $y$ の関係の グラフを図 4 に示す。これは直線状に見えるが，こう 配 $d y / d z_{G 2}$ は， $z_{G 2}$ が $0 \mathrm{~m}$ と $12 \mathrm{~m}$ のところでは約 2 倍 の開きがある。

$4 \cdot 2$ サーボ弁の圧力・流量特性 サーボ弁の特 性解析はこれまでに多数行われているが, 大部分は両 ロッドの対称シリンダの場合 ${ }^{(8)}$ であり，図 3 のような 
非対称シリンダに適用する場合には一般に $P_{1}-P_{2}$ が 負荷圧力として利用されている.しかし, シリンダ発 生力は式(13)から明らかなように

$$
P_{L}=P_{1}-\varepsilon P_{2}, \varepsilon=A_{D C 2} / A_{D C 1}
$$

に依存しており， $P_{1}-P_{2}$ には物理的意味がないように 思われる.そこで $4 \cdot 2$ 節では上記の $P_{L}$ を負荷圧力と 定義し, $P_{L}$ と負荷流量

$$
Q_{L}=\left(Q_{1}+Q_{2}\right) /(1+\varepsilon)
$$

の準静的な関係を求める.

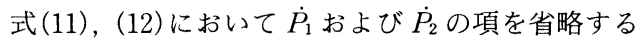
と, $Q_{1}=Q_{L}, Q_{2}=\varepsilon Q_{L}$ となる.これを用いて, 式 (16)，(17) から $P_{1}$ と $P_{2}$ を計算し, それを式(27)に代 入すれば,

$$
Q_{L}=K_{Q} u\left[\left(P_{S}-P_{L}\right) /\left(1+\varepsilon^{3}\right)\right]^{1 / 2}, u \geq 0
$$

となる，同様に式(18), (19) から

$$
Q_{L}=K_{Q} u\left[\left(\varepsilon P_{S}+P_{L}\right) /\left(1+\varepsilon^{3}\right)\right]^{1 / 2}, u<0
$$

が得られる.ただし，ここでは $0 \leq P_{1}, P_{2} \leq P_{S}$ と仮定

している.

式(29)，(30)をグラフにすると図 5 が得られる. 図 中では, 近似式 $u=K_{u} i$ を用いて曲線群のパラメータ を弁開度 $u$ から入力電流 $i$ に変換している. また, 高 所作業車が静止状態(この状態での変数の值は “*”印 で表す)にあるときの $\beta$ と $P_{L}$ の関係も同時に示して いる. 図 5 から, 例えば $\beta^{*}=100^{\circ}\left(z_{G 2}=0 \mathrm{~m}\right)$ では, 電 流に対するピストン速度 $Q_{L} / A_{D C 1}$ のゲインは, 電流の 正負によって 1.6 倍の開きがあることがわかる.

$4 \cdot 3$ サーボ弁の線形化 図 5 において, $P_{L}$ が約 $5 \mathrm{MPa}$ の所では, 電流に対するピストン速度のゲイン は電流の正負によらず一定となっている，この状態を 保つために電流指令值 $i_{C}$ を導入し， $i_{C}$ から実際の電 流 $i$ を次式で計算するものとする.

$$
i=K_{c}\left(P_{L}\right) i_{C}
$$

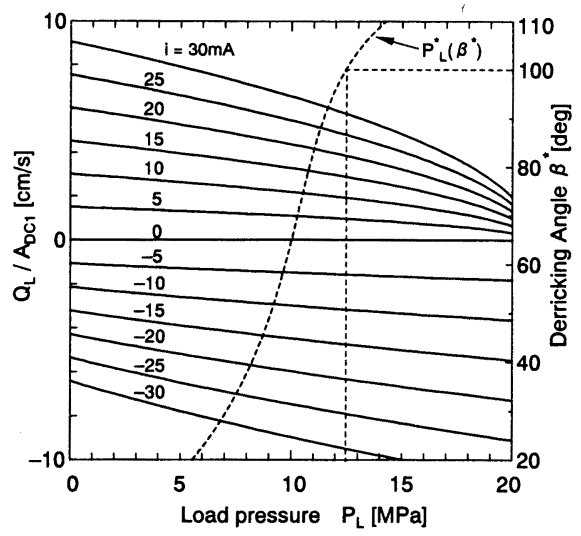

Fig. 5 Nonlinear characteristics of servo valve
ここで, 電流補正ゲインは

$$
K_{C}\left(P_{L}\right)= \begin{cases}{\left[(1+\varepsilon) P_{S} / 2\left(P_{S}-P_{L}\right)\right]^{1 / 2},} & i_{C} \geq 0 \\ {\left[(1+\varepsilon) P_{S} / 2\left(\varepsilon P_{S}+P_{L}\right)\right]^{1 / 2},} & i_{C}<0\end{cases}
$$

となる.このとき $i_{C}$ と負荷電流 $Q_{L}$ の関係は図 6 と なり, 飽和に達しない範囲では次式のように線形関係 となっている.

$$
\begin{aligned}
& Q_{L}=K_{Q C} i_{C} \cdots \cdots \ldots \ldots \ldots \ldots \ldots \ldots \ldots \ldots \ldots \ldots \ldots \ldots \\
& K_{Q C}=K_{Q} K_{u}\left[(1+\varepsilon) P_{S} / 2\left(1+\varepsilon^{3}\right)\right]^{1 / 2}
\end{aligned}
$$

$4 \cdot 4$ モード展開 制御量 $y$ の簡単なモデルを作 るための準備として, 線形化した運動方程式に基づい て $y$ のモード展開を行う. 高所作業車が静止状態か らわずかに変位した $\boldsymbol{q}=\boldsymbol{q}^{*}+\Delta \boldsymbol{q}$ の状態を考えると, $\boldsymbol{F}_{\text {out }}=0$ の場合, $\Delta \boldsymbol{q}$ の方程式は式 (6) から次のように 近似される。

$$
\begin{gathered}
\boldsymbol{M}\left(\boldsymbol{q}^{*}\right) \Delta \ddot{\boldsymbol{q}}+\boldsymbol{C}\left(\boldsymbol{q}^{*}\right) \Delta \dot{\boldsymbol{q}}+\tilde{\boldsymbol{K}}\left(\boldsymbol{q}^{*}\right) \Delta \boldsymbol{q} \\
\quad=\boldsymbol{B}\left(\boldsymbol{q}^{*}\right) A_{D C 1} \Delta P_{L} \ldots \ldots \ldots \ldots \ldots \ldots \ldots \ldots \ldots \ldots \ldots
\end{gathered}
$$

ここで,

$$
\begin{aligned}
& \widetilde{\boldsymbol{K}}\left(\boldsymbol{q}^{*}\right)=\boldsymbol{K}\left(\boldsymbol{q}^{*}\right) \\
& \quad+\left\{\frac{\partial}{\partial q}\left[\boldsymbol{K}(\boldsymbol{q}) \boldsymbol{q}^{*}-\boldsymbol{B}(\boldsymbol{q}) F_{D C}{ }^{*}-\boldsymbol{G}(\boldsymbol{q})\right]\right\}_{q=q^{*}}
\end{aligned}
$$

$A_{D C 1} \Delta P_{L}=F_{D C}-F_{D C} *$

一方, 式(11)，(12)において $V_{1}=\varepsilon V_{2}$ の場合(ピス トンがシリンダのほぼ中央にある場合.このときの $V_{1}$ の值を $V_{m}$ と表す)を考えると，両式を加算して $1+\varepsilon$ で割り,さらに, $\dot{r}=\boldsymbol{B}\left(\boldsymbol{q}^{*}\right) \Delta \dot{\boldsymbol{q}}$ を代入すると, 次 式が得られる。

$$
Q_{L}=A_{D C 1} \boldsymbol{B}\left(\boldsymbol{q}^{*}\right) \Delta \dot{\boldsymbol{q}}+\frac{V_{m}}{(1+\varepsilon) K_{\mathrm{oll}}} \Delta \dot{P}_{L}
$$

式(33)，（35)および式(38)を状態変数 $\boldsymbol{x}=\left[\Delta P_{L}\right.$, $\left.\Delta q^{T}, \Delta \dot{q}^{T}\right]^{T}$ と入力 $i_{C}$ に関して状態変数形式にまとめ,

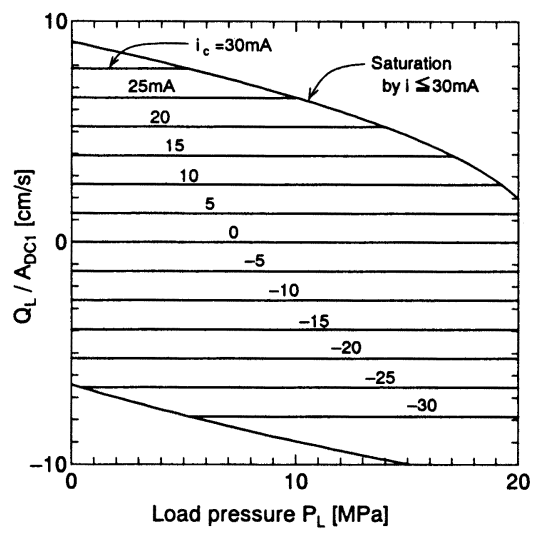

Fig. 6 Linearized characteristics of servo valve 
そのシステム行列の沽有值と固有ベクトルを求めてモ ード殿開すると, $\Delta \dot{\boldsymbol{q}}$ は次のような形になっている。

$$
\Delta \dot{\boldsymbol{q}}=\left[\sum_{l} \frac{\boldsymbol{T}_{1}+\boldsymbol{F}_{l}}{s^{2}+a_{1}+b_{l}}+\sum_{m} \frac{\boldsymbol{\Psi}_{m}}{s+\lambda_{m}}\right] i_{c}
$$

ここで，右边カッコ内の第10 $\Sigma$ は複素共役対の固 有値，第20 $\sum$ は央数の固有值にそれぞれ対応して いる， $\boldsymbol{T}, \boldsymbol{F}, \boldsymbol{\Psi}$ は $\Delta \boldsymbol{q}$ と同じ次元の定数べクトル， $a, b, \lambda$ は先数である。长式から $\dot{y}=\boldsymbol{H}^{T}\left(\boldsymbol{q}^{*}\right) \Delta \dot{\boldsymbol{q}}$,

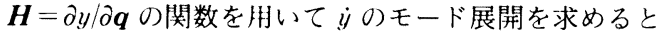
次式となる．数值は $\beta^{*}=100^{\circ}$ の場合の值である.

$$
\begin{aligned}
\dot{y}= & {\left[\frac{0.011 s+2.99}{s^{2}+0.32 s+11.6}-\frac{0.00011 s+0.017}{s^{2}+0.66 s+46.1}\right.} \\
& \left.-\frac{0.015 s+4.02}{s^{2}+4.2 s+423}+\frac{0.00003 s+0.052}{s^{2}+5.7 s+561}+\cdots\right] i_{C}
\end{aligned}
$$

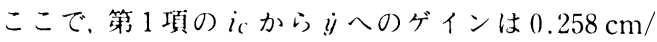
$\mathrm{s} / \mathrm{mA}$ であるが、别の計算によれば、全モードに関す るゲインの和は 0.246 であるから、この第 1 項のみで $90 \%$ 以上の近似となっていることがわかる. 式(40)の 四つの項に対するモード形状を図 7 に示す。これは

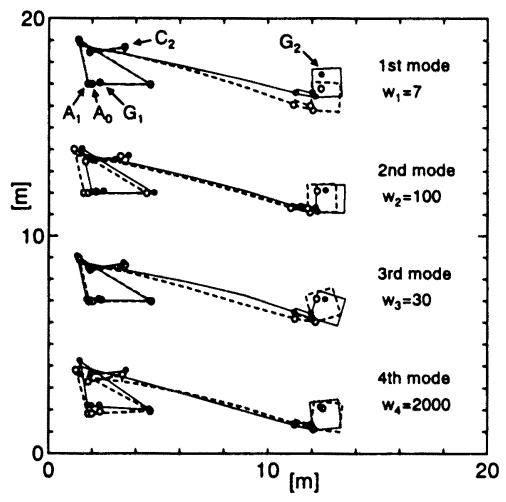

Fig. 7 Mode shapes at $\beta^{*}=100$

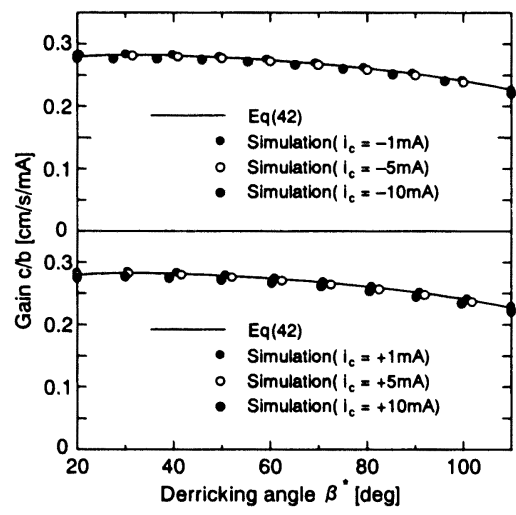

Fig. 8 Gain between velocity $\dot{y}$ and current $i_{c}$ $w_{1}=7, w_{2}=100, w_{3}=30, w_{4}=2000$ として $\boldsymbol{q}=\boldsymbol{q}^{*}$ $\pm w_{l} \boldsymbol{F}_{l}, l=1,2,3,4$ に対する高所作業車のスケルト ムを示したものである.

$4 \cdot 5$ 制御モデル $4 \cdot 4$ 節の結果に基づいて, 制御 量 $y$ のデルを

$$
\dot{y}=\frac{c}{s^{2}+a s+b} i_{c}
$$

とする. 係数 $a, b, c$ は各モード展開からは正確に求 まらないので $\left(V_{1}=\varepsilon V_{2}\right.$ が成立しない)，ステップ応 答のシミュレーションからこれらを算出した結果を図 $8 \sim 10$ に示す. 図 8 はゲイン $c / b$ を示したものであり,

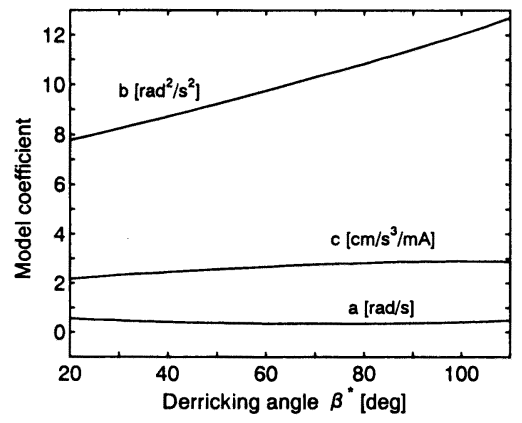

Fig. 9 Coefficients of the model transfer function

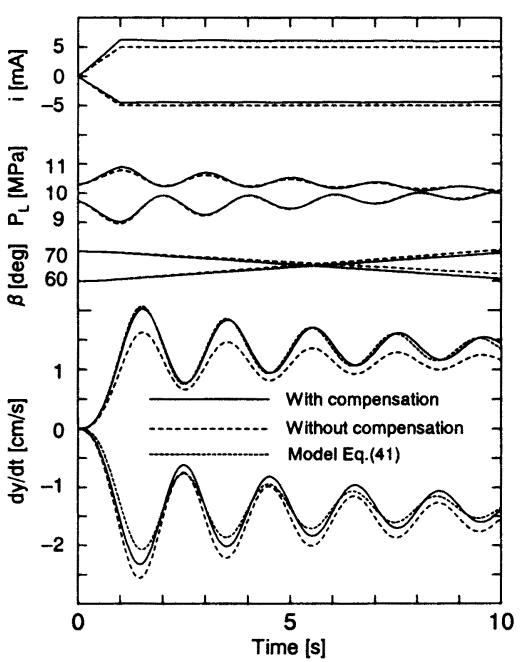

Fig. 10 Time histories for the step like change of current $i_{c}$

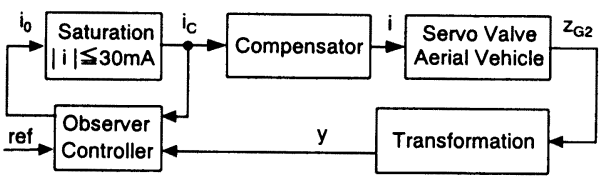

Fig. 11 Block diagram of control system 
実線は式(33)から導かれる理論値

$$
\frac{c}{b}=\frac{K_{Q C}}{A_{D C 1}} \frac{d y^{*}}{d r^{*}}
$$

を示している. シミュレーション值と理論值は $i_{C}$ の 正負に関係なくほぼ一致していることがわかる.図 9 は $a, b$ をステップ応答の振動波形から求め, cを式 (42) から計算した結果である.図 10 は， $i_{c}= \pm 5 \mathrm{~mA}$ のステップ状変化に対する諸量の時刻歴の一例であ る. 補正がない場合 $\left(K_{C}=1\right)$ には, $i_{C}$ の正負によっ て $\dot{y}$ の平均レベルの絶対值が異なっていることがわ かる.

\section{5. 制 御 則}

図 11 に制御系のブロック線図を示す。この線図の 意味は, まず電流指令値 $i_{C}$ をえ, 式(31) からサーボ 弁入力電流を求める. そしてバケットの高さ $z_{G 2}$ を式 (21)〜 (26) を用いて制御量 $y$ に変換する. 次に, $y$ が その目標値に追従するように $i_{C}$ の仮の值 $i_{0}$ を計算し, 電流の飽和を考慮して $i_{C}$ を決定する.ただし，i 含まれる $y$ とその微分值はオブザーバによる推定值 で置換するというものである.

$i_{0}$ を計算するための $y$ のモデルとして, 式(41)に入 力外乱 $e$ を付加した次式

$$
\dddot{y}+a \ddot{y}+b \dot{y}=c\left(i_{0}+e\right)
$$

を使用する。そして, 目標値 $y_{\text {ref }}$ に対する追従䛊差0) 挙動を

$$
(d / d t+\omega)^{3}\left(y_{r e f}-y\right)=0
$$

によって指定すると, 両式から $\dddot{y}$ を消去することによ って, 次式が得られる.

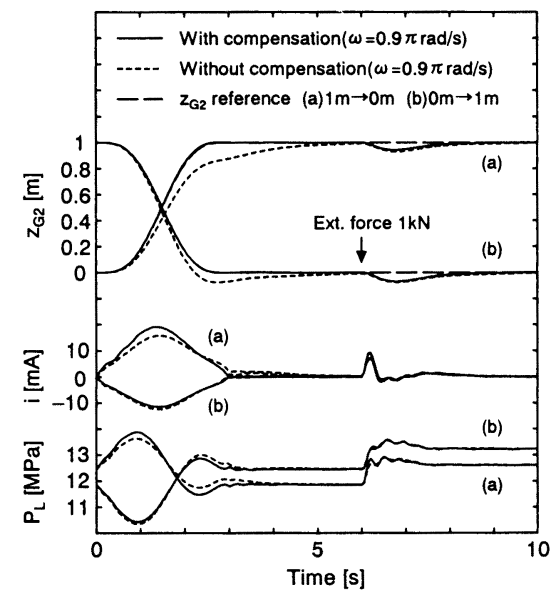

Fig. 12 Control results for a smooth altitude change of the bucket gravity center

$$
\begin{aligned}
i_{0}= & g_{1}\left(y_{r e f}-y\right)-g_{2} \dot{y}-g_{3} \ddot{y}-\iota^{\prime} \\
& +\dddot{y}_{r e f}+3 \omega \ddot{y}_{r e f}+3 \omega^{2} \dot{y}_{r e f} .
\end{aligned} .
$$

ここで, $g_{1}=\omega^{3} / c, g_{2}=\left(3 \omega^{2}-b\right) / c, g_{3}=(3 \omega-a) / c$ は フィードバックゲインである。一方，武(45)に含まれ る $y, \dot{y}, \ddot{y}$ およびのを推定するために、式(43)でi。 $i_{c}$ で置換えた式抢よび $\dot{c}=0$ を用いてオブザーバを 構成すると,よく知られているように

$$
\frac{d}{d t} \hat{\boldsymbol{X}}=\boldsymbol{A} \hat{\boldsymbol{X}}+\boldsymbol{B} i_{c}+\boldsymbol{G}_{o b s}(y-\boldsymbol{H} \hat{\boldsymbol{X}})
$$

の形の式が得られる。ここで, $\hat{\boldsymbol{X}}$ は $\boldsymbol{X}=\left[y, \dot{y}, \ddot{y}, c^{\top}\right]^{T}$ 0)推定値, $\boldsymbol{G}_{\text {obs }}$ はオブザーバゲインベクトル，Hは $[1,0,0,0]$ である。

\section{6. シミュレーション}

活線作業用高所作業東では、マニピュレータハンド を作業位㯰に移動させるために，バケットを指定され た軌道，例えば，電線に斗行な水斗軌道や集消に斗行 な垂直軌道に汾って移動させなければならない。こ0

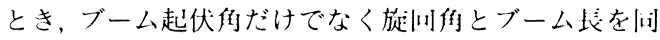
時に制御しなければならないが、本論文ではそのよう な三次元的軌道制御を行うための第一段階として。起 伏解のみによる追従制御のシミュレーションを行一 た。シミュレーションの啲は，提案した制御系の㚣 分性と追従精度の検則である。

パラメー夕等に関する条件は次のとおりである。

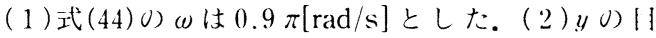

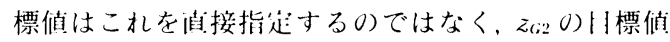

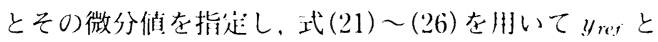

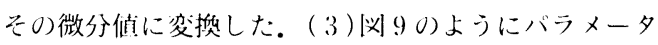
はバケットの仿湴によ一て変化するいで、これに刘伈 してフィードバックゲイン $g_{1} \sim g_{3}$, オブ+゙ーバゲイン

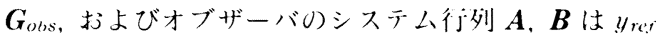

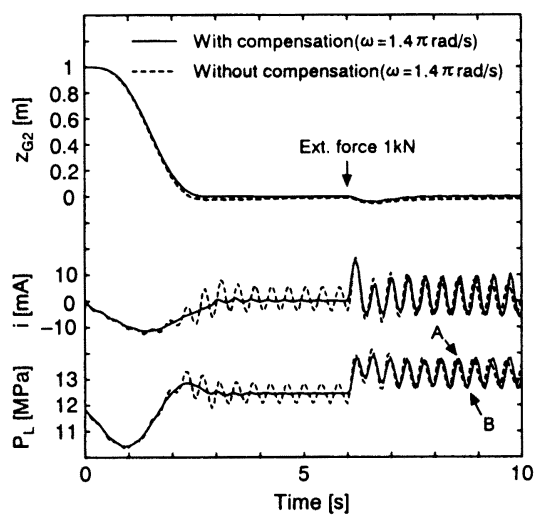

Fig. 13 Unstability caused by a large feedback gain 


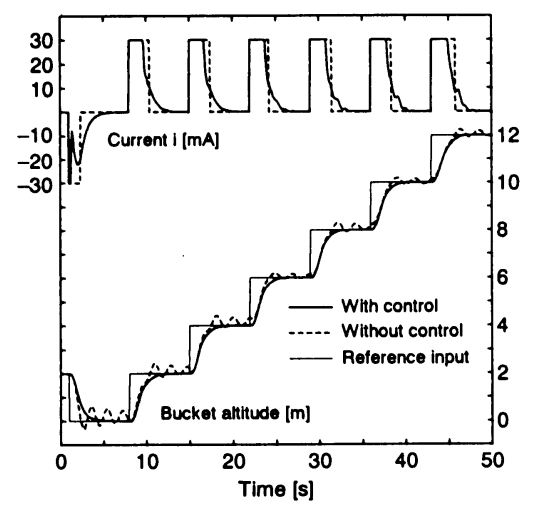

Fig. 14 Control result when the input current is saturated by the sudden change of reference input where model parameters are constants corresponding to $\beta^{*}=65$

の值に基づいて変換した（4) オブザーバゲインは適 当な重み行列とリカッチ方程式を用いて計算したが, $y_{r e r}=2.02 \mathrm{~m}\left(\beta^{*}=65^{\circ}\right)$ の位置ではオブザーバの主要 極の配置は $s=-20.0,-14.0 \pm 14.3 \mathrm{rad} / \mathrm{s}$ となって いる.

バケットが低い範囲で位置変更を行うときは高所作 業車が最も拢動しやすいので、汹 12 は $1 \mathrm{~m}$ と $(0 \mathrm{~m}$ の 間でバケットの位置を変吏させ，追従動作を検討した 結果である。さらに制御系の安定性を検討するため， $t=6$ 秒で鉛值下向の $1 \mathrm{kN}$ の外力を作用させた，位 置変更のための $z_{G 2}$ の目標値は時間の 7 次多項式で作 成したが、図から電流補正を行った場合にはそうでな い場合に比べて，目標值の過渡波形によく追従してい ることがわかる，また，外力に対して安定な動作をし ていることがおかる。

図 13 は，図 12 と同じ条件で式(44)の $\omega$ のみを 0.9 $\pi$ から $1.4 \pi[\mathrm{rad} / \mathrm{s}]$ に変更した場合である。電流補 正の有無に関係なく, 電流と解荷圧力に発振が生じて

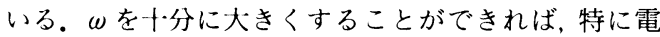
流補正をしなくても追従精度は向上するが, 図 13 は $\omega$ を十分に大きく取れないこと、したがって電流補正 が必要であることを示している。発振するモードとし ては、四中の 2 点 $\mathrm{A}, \mathrm{B}$ の変数 $\boldsymbol{q}$ の值を $\boldsymbol{q}_{A}, \boldsymbol{q}_{B}$ とし,

$$
\boldsymbol{q}=\left(\boldsymbol{q}_{A}+\boldsymbol{q}_{B}\right) / 2 \pm 100\left(\boldsymbol{q}_{A}-\boldsymbol{q}_{B}\right)
$$

に対する高所作業車のスケルトンを作四すると、これ が戍 70 三次モードの場合と同じ形になることから， 三次モードの発振であると推定される。なお， きくした場命の発振限界はバケットの位置によって異 なり， $\beta^{*}=650$ の近辺では $8 \pi[\mathrm{rad} / \mathrm{s}], \beta^{*}=100^{\circ}$ の近 辺では $3 \pi[\mathrm{rad} / \mathrm{s}]$ となった。

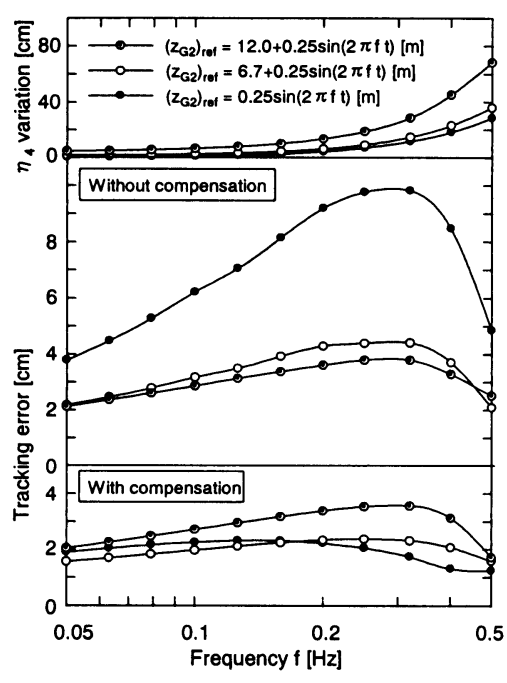

Fig. 15 Tracking error for the sinusoidal reference input of the bucket altitude

図 14 は極端な例として, バケット位置を最も速く 変化させるために目標值をステップ状に変化させた場 合である、サーボ弁入力電流が緩和しているが, 図 14 からわかるようにオーバシュートなしに安定に動作し ている。なお，この例では制御系のモデルパラメータ に対するロバスト性を調べるためにモデルパラメータ は $\beta^{*}=65^{\circ}\left(z_{G 2}{ }^{*}=6.7 \mathrm{~m}\right)$ のもののみを用いて, $0 \mathrm{~m}$ と $12 \mathrm{~m}$ の間で $2 \mathrm{~m}$ ずつバケットを移動させた.

図 15 は，提案した制御系の追従精度を検討するた め, $z_{G 2}$ の目標值を中心高度 $0 \mathrm{~m}, 6.7 \mathrm{~m}, 12.0 \mathrm{~m}$, 振 幅 $50 \mathrm{~cm}$, 周波数 $0.05 \sim 0.5 \mathrm{~Hz}$ の正弦波とした場合 の 1 サイクル中の最大追従誤差を示している. $z_{G 2}$ の 中心高度が $0 \mathrm{~m}, 6.7 \mathrm{~m}, 12.0 \mathrm{~m}$ のいずれの場合と電 流補正によって誤差は小さくなっているが, 特に振動 しやすい $0 \mathrm{~m}$ の場合には $1 / 5$ 程度までに減少し, 電流 補正の効果が現れている。

\section{7. 結言}

ここでは活線作業用高所作業車のバケットの軌道制 御の第一歩として, 起伏シリンダに取付けられたサー ボ弁でバケットの上下動を制御する方法を提案した. 具体的には, 文献 (4)に示された高所作業車の運動方 程式をサーボ弁で駆動する場合へ再編成し，電流補正 ゲインを導入してサーボ弁の線形化を行い, これらに 基づいて, バケットの重心の高さに対応する制御量の 簡単なモデルと制御則を導出した. シミュレーション では, バケットの高さの変更や正弦波軌道への追従に おいて妥当な結果が得られた。 今後の課題は, ブーム 
の伸縮および旋回動作を含む場合の三次元軌道制御法

の構成, 画像処理によるバケット位置のオンライン計 測法の開発である.

\section{文献}

（1）仁尾理・ほか 4 名，活線作業ロボットの開発，54-206 (1990), 89-101, 安川電機.

（2）九州電力編, 停電現象と配電作業の近代化一作業停電の 解消と活線作業用ロボットの開発一, 九州電力パンフレ ット, (1994), 1-7.

(3) Maruyama, Y., Yano, K. and Nakashima, M., Application of Semi-Automatic Robot Technology on Hot-
Line Maintenance Work, Proc. Distribution 2000, (1995), 333-338, Brisbane.

（4）内原勇・ほか 3 名, 高所作業車のモデリングと振動制御 に関する研究(第 1 報, 起伏動作の場合), 機論, 64-625, C (1998), 3405-3413.

（5）内原勇・ほか 2 名, 高所作業車のモデリングと振動制御 に関する研究(第 2 報, 起伏と旋回を同時に考慮した場 合), 機論, 66-646, C (2000), 1800-1809.

（6）阿波啓造・ほか 2 名，片ロッドシリンダを有する電気油 圧サーボ機構の高精度連続軌跡制御, 油圧と空気圧, 16-7 (1985), 522-529.

（7）横田真一・ほか 2 名, 油圧ショベルのブーム,アーム系の 高精度軌跡制御, 機論, 62-593, C (1996), 161-167.

（8）山口嵉・田中裕久, 油空圧工学, (1986), 79, コロナ社. 